\title{
Nytt genkart for multippel sklerose
}

\begin{abstract}
Sammendrag
Bakgrunn. Multippel sklerose (MS) er en demyeliniserende, inflammatorisk sykdom i det sentrale nervesystemet som rammer unge voksne og medfører attakkvis eller jevnt progredierende sentralnervøse utfall. Både miljøfaktorer og genetiske faktorer påvirker risikoen for utvikling av sykdommen, men årsaken er ellers ikke kjent.

Materiale og metode. Det gis en oversikt over ny kunnskap vedrørende genetiske faktorer som er assosiert med utvikling av multippel sklerose. Artikkelen er basert på eget arbeid samt gjennomgang av litteratur innen dette forskningsfeltet.
\end{abstract}

Resultater. Gjennom genomvide assosiasjonsstudier, der man kombinerer ny genetisk teknologi og store pasientkontroll-materialer, er det de siste årene identifisert en rekke gener av betydning for utviklingen av multippel sklerose. Nylig publiserte International MS Genetics Consortium i samarbeid med Wellcome Trust Case Control Consortium en genomscreening av 9772 multippel sklerose-pasienter og 17376 kontrollpersoner. Sikker assosiasjon $\left(p<10^{-8}\right)$ ble påvist for 29 nye og 23 tidligere identifiserte genregioner i denne studien, i tillegg til HLA-DRB1og -A-alleler. Hovedandelen av de assosierte genregionene koder for immunrelaterte molekyler.

Konklusjon. I store internasjonale og nasjonale samarbeidsprosjekter har man identifisert over 50 genregioner i tillegg til flere HLA-alleler som hver for seg øker risikoen moderat for å utvikle multippel sklerose. Disse studiene bekrefter at immunologiske signalveier er sentrale for utvikling av sykdommen.

\section{Hanne F. Harbo}

h.f.harbo@medisin.uio.no

Nevrologisk avdeling

Oslo universitetssykehus, Ullevål

og

Universitetet i Oslo

Åslaug R. Lorentzen*

Nevrologisk avdeling

Oslo universitetssykehus, Ullevål

\section{Benedicte A. Lie}

Immunologisk institutt

Oslo universitetssykehus, Rikshospitalet og

Avdeling for medisinsk genetikk

Universitetet i Oslo/Oslo universitetssykehus

\section{Elisabeth Gulowsen Celius}

Nevrologisk avdeling

Oslo universitetssykehus, Ullevål

\section{Anne Spurkland}

Institutt for medisinske basalfag

Universitetet i Oslo

* Nåværende adresse:

Vågsbygd legesenter, Kristiansand

Multippel sklerose (MS) er en demyeliniserende inflammatorisk sykdom i sentralnervesystemet som vanligvis debuterer hos unge voksne og gir opphav til varierende, men ofte alvorlige nevrologiske utfall. Årsaken er ukjent, men man antar at både miljøfaktorer og genetiske faktorer bidrar til utvikling av sykdommen. Inntil nylig har det kun vært HLA-gener som med sikkerhet er funnet assosiert med multippel sklerose, og den sterkeste assosiasjonen er påvist til HLADRB1*1501-allelet og haplotypen HLADRB1*1501-DQB1*0602. Bidraget fra dette genområdet er i størrelsesorden $20-60 \%$ av den totale genetiske disposisjonen (1).

Med nye genetiske teknikker og større materialer av DNA-prøver fra pasienter og kontrollpersoner klarte man i 2007, 35 år etter at HLA-assosiasjonen ved multippel sklerose først ble påvist, med sikkerhet å identifisere gener som disponerer for denne sykdommen også utenfor HLA-komplekset (2). Det har vist seg at disse genvariantene i relativt beskjeden grad bidrar til økt sykdomsrisiko, illustrert ved lave oddsratioer. Denne kunnskapen har ført til erkjennelsen av at det i de fleste tidligere studier har vært inkludert for få pasienter til at man har kunnet påvise sikre genetiske bidrag til sykdomsrisikoen. Takket være utvikling av ny teknologi som tillater rask analyse av et stort antall prøver og genområder, samt omfattende internasjonalt samarbeid, har man nå lyktes i å fremskaffe store nok pasient- og kontrollmaterialer til å kunne identifisere nye multippel sklerose-gener.

\section{Materiale og metode}

Vi gir en oversikt over ny kunnskap vedrørende genetiske faktorer som er assosiert med utvikling av multippel sklerose. Artikkelen er basert på vår egen forskning i Oslo MS genetikk gruppe samt gjennomgang av litteratur vi vurderer som sentral. Spesielt har vi lagt vekt på samarbeidet i International MS Genetics Consortium (IMSGC) og resultatene fra den nylig publiserte genomvide screeningen av multippel sklerose-pasienter og kontrollpersoner (3).

\section{Generelt om multippel sklerose}

Multippel sklerose er en inflammatorisk sykdom som affiserer sentralnervesystemet og som resulterer i demyelinisering og aksonskade. Sykdommen er en av de vanligste årsakene til invaliditet hos unge voksne. Hyppige symptomer er sensibilitetsforstyrrelser, motoriske vansker, redusert syn, balanseproblemer, kognitive vansker, fatigue og blære- og tarmproblemer. Hos 80-85\% debuterer sykdommen med attakkvise forverringer, såkalt attakkvis eller «relapsingremitting multiple sclerosis» (RRMS). Mellom attakkene kan pasienten ha stabile faser, men flertallet vil etter hvert utvikle en sekundær progrediering (sekundær progredierende multippel sklerose). $15-20 \%$ av pasientene viser jevn sykdomsprogrediering fra debuten, såkalt primær progredierende multippel sklerose.

Det finnes så langt ingen behandling som med sikkerhet stopper sykdomsutviklingen. Av de immunmodulerende medikamentene som i dag er registrert for behandling av multippel sklerose i Norge, reduserer interferoner og glatirameracetat attakkfrekven-

\section{Hovedbudskap}

- Nylig er det påvist en rekke genregioner som gir økt risiko for å utvikle multippel sklerose

- HLA-DRB1*15-allellet gir høyest multippel sklerose-risiko

- Øvrige genregioner bidrar med moderat risiko for sykdommen

- Risikogenene koder hovedsakelig for immurelaterte molekyler 
sen med ca. $30 \%$, fingolimod med $54 \%$ og natalizumab med $68 \%$. En rekke nye medikamenter er på vei. Felles for disse synes å være at jo mer effektive de er, desto større er risikoen for alvorligere bivirkninger (4).

Nyere studier viser at prevalensen av multippel sklerose i Norge er ca. 150 tilfeller per 100000 innbyggere, 170 per 100000 når ikke-vestlige innvandrere er ekskludert (5). Dette er en hyppig forekommende sykdom i Europa, USA, Canada, Sørøst-Australia og New Zealand. I Midtøsten og vestlige deler av Asia er forekomsten lavere, men den er høyere enn i de østlige delene av Asia. Enkelte etniske grupper, f.eks. samene, har lavere prevalens enn befolkningen ellers i samme område (6). Både genetiske faktorer og miljøfaktorer antas å være av betydning for den varierende forekomsten i ulike folkegrupper. Insidensen av sykdommen har økt de siste 30-40 årene, og økningen er størst for attakkvis multippel sklerose (RRMS) og blant kvinner (7).

\section{Arv eller miljø?}

Ca. $20 \%$ av pasientene rapporterer at de har slektninger med multippel sklerose. Risikoen hos søsken for å få sykdommen er 3-5\%, mens konkordansen for eneggede tvillinger er rundt 30\% (8). Forskjellen i risiko mellom eneggede og toeggede tvillinger tyder på at det finnes gener som disponerer for multippel sklerose, men at også andre faktorer påvirker sykdomsrisikoen. Den relativt lave økningen i risiko blant slektninger til pasientene tyder også på at bidraget fra genetiske faktorer til den totale sykdomsrisikoen er moderat.

Hvor pasienten er født og oppvokst og vedkommendes alder ved eventuell migrasjon har betydning for sykdomsrisikoen (9). Dette indikerer at den genetiske disposisjonen varierer i ulike befolkningsgrupper samt at miljøfaktorer kan påvirke risikoen. Sannsynligvis virker miljøfaktorene på individet mange år før sykdommen diagnostiseres, og studier av deres betydning er derfor vanskelig å gjennomføre. Den geografiske variasjonen i forekomsten av multippel sklerose, samt funn av lave D-vitaminnivåer hos unge menn som senere har fått sykdommen, er indikasjoner på at lavt nivå av dette vitaminet kan være en risikofaktor $(10,11)$. Det er også stadig flere holdepunkter for at EpsteinBarr-virusinfeksjon i sen ungdomstid eller i voksen alder (12) samt røyking (13) er risikofaktorer. Mange andre miljøfaktorer er studert, men så langt har man ikke med sikkerhet kunnet fastslå hvilke andre faktorer som også kan ha betydning.

Alt i alt gir nyere forskning støtte til hypotesen om at multippel sklerose forårsakes av et samspill mellom arvelige faktorer og miljøfaktorer. Den betraktes derfor som en multifaktoriell og genetisk kompleks eller polygen sykdom, der kartlegging av de ulike årsaksfaktorene kan gi mulighet for bedre diagnostikk og terapi.

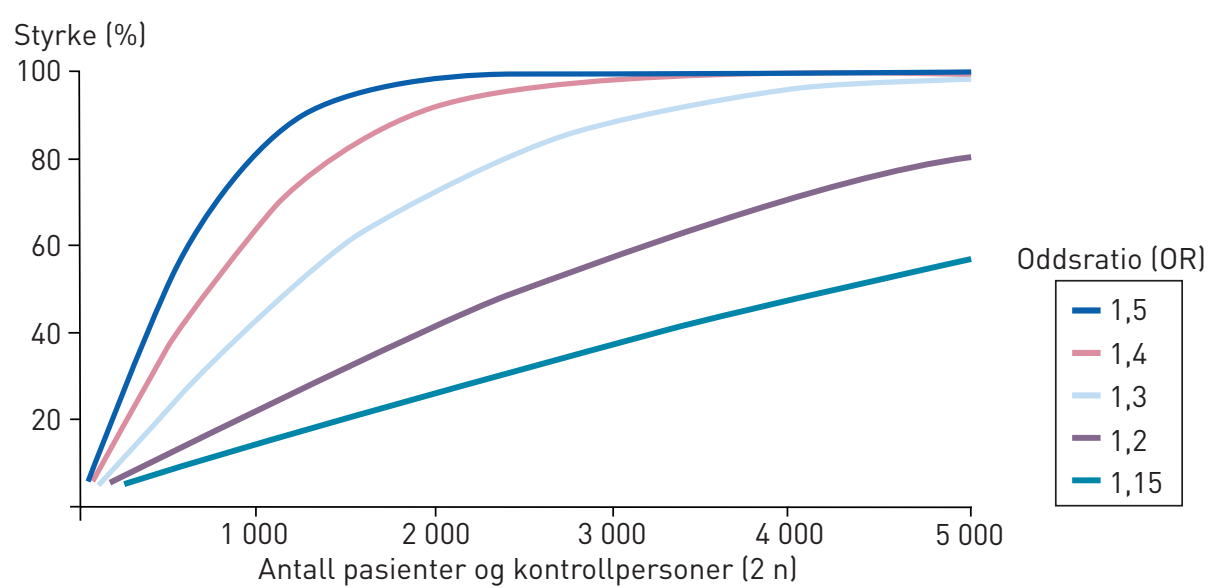

Figur 1 Korrelasjonen mellom statistisk styrke, antall pasient-kontroll-prøver og oddsratio (OR) for genvarianter med en allelfrekvens over $10 \%$ ved signifikansnivå $p=0,05$. Figuren viser at det kreves flere tusen par pasient-kontroll-prøver for å kunne oppå signifikante resultater i genetiske studier av en sykdom som multippel sklerose, der risikoallelene antas å forekomme hyppig i befolkningen (f.eks. allelfrekvens over 10\%) og risikoen for sykdom forbundet med hvert enkelt gen er relativt lavt (lav OR). Utgangspunktet for figuren er programmet PS power calculator version 2.1.31 (28)

\section{HLA-assosiasjon \\ ved multippel sklerose}

Det har vært kjent i snart 40 år at visse HLAgener (humant leukocyttantigen) disponerer for multippel sklerose $(14,15)$. HLA-molekylene har en viktig funksjon i immunsystemet ved at de presenterer deler av nedbrutte proteiner (peptider) for immunapparatets Tceller. Dette er viktig for at kroppen skal oppdage fremmede inntrengere som bakterier og virus. Normalt reagerer ikke immunapparatet på kroppsegne peptider presentert av HLA-molekyler. Ved autoimmune sykdommer, derimot, mistolker immunapparatet visse kroppsegne antigener som fremmede og går til angrep på sitt eget vev. At bestemte varianter av HLA-gener disponerer for multippel sklerose, er dermed godt forenlig med patologiske og immunologisk studier av sykdommen, som også peker mot at den er immunmediert (16).

I 1972 ble assosiasjon til HLA-klasse Iallelene HLA-A3 (15) og HLA-B7 (14) ved multippel sklerose påvist ved HLA-typing av kun rundt 100 pasienter og kontrollpersoner. Assosiasjon til HLA-klasse II-allelet DR2 (tilsvarer DRB1*1501 ved genomisk typing) ble påvist året etter (17). Tidlig i 1990-årene viste man at HLA-A3- og B7assosiasjonene i stor grad skyldes at disse allelene nedarves sammen med HLADRB1*1501-DQB1*0602 (18), som man nå vet gir det sterkeste genetiske bidraget til multippel sklerose i de fleste populasjoner. Men HLA-DRB1*1501-allelet forklarer ikke hele det genetiske bidraget fra HLAkomplekset. Også andre HLA-DRB1- og -DQB1-alleler er av betydning. Ved å studere populasjoner hvor frekvensen av HLADRB1*1501 er lav, har man funnet at HLADRB1*03 øker risikoen for multippel sklerose, mens HLA-DRB1*01-allelet gir redusert risiko (19). Det er også rapportert samspillseffekter av allelene i HLA-klasse
II-regionen (inkludert HLA-DRB1, -DQB1 og -DQA1) (20).

Relativt nylig har man påvist at HLAklasse I-locuset likevel bidrar til genetisk risiko ved multippel sklerose uavhengig av klasse II-gener. Blant nordiske pasienter har man funnet at HLA-A2-allelet beskytter (21), mens HLA-A3 disponerer for sykdommen (22). Det er foreslått at også andre klasse I-gener, blant annet HLA-C5 (23) og HLA-B44 (24), bidrar til sykdomsrisikoen. Vi har nylig beskrevet en assosiasjon til HLA-B-alleler som koder for et bestemt bindingssete for «killer-cell immunoglobulinlike receptor» (KIR) (25). Dette er inhibitoriske reseptorer som uttrykkes av naturlige drepeceller (NK-celler) og som er viktige for å holde disses aktivitet under tett kontroll. HLA-klasse I-molekylene kan bidra til multippel sklerose gjennom presentasjon av antigener til T-celler, tilsvarende som for HLA-klasse II-molekylene. KIR/HLA-studier tyder imidlertid på at HLA-klasse Imolekylene også kan bidra til utvikling av multippel sklerose via påvirkning av de naturlige drepecellenes funksjon (25-27).

\section{Leting etter andre kandidatgener}

Påvisning av HLA-assosiasjonen ved multippel sklerose førte til en rekke studier av andre kandidatgener i relativt små materialer (typisk 100-300 prøver) av pasienter og kontrollpersoner i 1990-årene. Spesielt immunrelaterte gener og gener av betydning for demyelinisering ble studert. Det ble rapportert en rekke positive assosiasjoner, med p-verdier omkring $5 \%$, som ikke lot seg bekrefte i påfølgende studier. I og med at hvert enkelt multippel sklerose-gen har vist seg å gi relativt små bidrag til sykdomsrisikoen, vet vi i dag at disse tidligere studiene som regel ikke inkluderte mange nok prøver. De hadde derfor for lav statistisk styrke (evne til å forkaste en nullhypotese når den 
ikke stemmer) til å kunne bekrefte eller avkrefte en mulig genetisk assosiasjon ved multippel sklerose (28) (fig 1).

Da man i 1990-årene ved bruk av koblingsanalyser i familier klarte å identifisere en rekke gener som forårsaket monogene sykdommer, forsøkte man også ved komplekse sykdommer som multippel sklerose å bruke affiserte søskenpar for å gjennomføre koblingsundersøkelser av både hele genomet og av utvalgte kandidatgenregioner. Man fant imidlertid ingen genregioner som med sikkerhet var koblet til sykdommen, utenom HLA-regionen, som allerede var et etablert multippel sklerose-locus etter kandidatgenstudiene. I ettertid vet man at det ikke finnes store nok samlinger av søskenpar med sykdommen til å kunne påvise de moderate genetiske bidragene utenfor HLAregionen ved multippel sklerose ved hjelp av koblingsanalyser (29). Det finnes heller ikke store nok familier med opphopning av sykdommen som kunne ha ført til gjennombrudd for den genetiske forskningen, slik det har vært tilfellet ved genetiske studier av for eksempel Parkinsons sykdom (30).

Store studier identifiserer nye gener Den moderate suksessen for genetisk multippel sklerose-forskning i 1990-årene førte til erkjennelsen av at det kreves store pasientmaterialer for å kunne identifisere nye genetiske risikofaktorer ved sykdommen. Som illustrert i figur 1 kreves det studier med flere tusen pasienter og kontrollpersoner for å oppnå stor nok statistisk styrke til å kunne påvise signifikante assosiasjoner av moderate genetiske bidrag $(28,29)$.

Denne erkjennelsen førte til etablering av multippel sklerose-biobanker og internasjonale samarbeidsprosjekter, der man fusjonerte genetiske analyser fra ulike populasjoner. I Norge etablerte man i 2005 en biobank knyttet til et nasjonalt multippel sklerose-register (31), og Norsk MS register og biobank har nå en samling på ca. 3000 DNA- og serumprøver, som allerede er benyttet i ulike typer genetiske studier $(3,32,33)$.

Etter at de første multippel sklerose-assosierte genene ble oppdaget i HLA-regionen i 1972, skulle det gå 35 år før man kunne peke ut andre gener av betydning. I 2007 lyktes man å identifisere to nye gener som med stor sikkerhet (genomvid signifikans, $\mathrm{p}<10^{-8}$ ) viste assosiasjon med sykdommen - interleukin 7-reseptor $\alpha$ (IL7Ra) og interleukin 2-reseptor $\alpha$ (IL2Ra) (2). Dette ble oppnådd gjennom en pasient-kontroll-studie med analyse av genmarkører spredt over hele genomet, en genomvid assosiasjonsstudie (genome-wide association study, GWAS). De samme to genregionene viste også sterk assosiasjon i uavhengige kandidatgenstudier $\mathrm{i}$ andre store pasientmaterialer, deriblant i vår nordiske studie $(34,35)$. Den genomvide signifikansgrensen er definert av en korreksjonsfaktor for det store antall statistiske tester som utføres når man
Tabell 1 HLA-alleler og andre genregioner assosiert med multippel sklerose i en genomvid assosiasjonsstudie (GWAS-studie) fra IMSGC-WTCCC fra 2011 (3). Fet skrift indikerer nye genregioner med bekreftet genomvid assosiasjon til multippel sklerose $(p<10-8)(n=29)$, rapporter i Nature (3). Tynn skrift på gennavn indikerer genregioner også identifisert i tidligere studier ( $\mathrm{n}=23$ )

Nærmeste gen til assosiert markør

Oddsratio (OR)

HLA-assosierte alleler $^{1}(\boldsymbol{n}=\mathbf{5}$ )

HLA-DRB*1501

3,08

HLA-DRB*1303

2,43

HLA-DRB*0301

1,26

HLA-DRB*0801

1,18

HLA-A*0201

Andre assosierte genregioner $(\boldsymbol{n}=52)$

GALC (GPR65)

CD86', PTGER4 ${ }^{1}$

CD581

TNFSF14 1 , MMEL 1(TNFRSF14), TMEM39A

EVI5, CLEC16A

SP140, IL22RA2

Ukjent gen komosom 3, MYB, TAGAP, CBLB

VCAM1 1', PVT1, MALT1', CYP24A1, RGS11, IL2RA', CD6, TNFRSF1A, IRF8'

Ukjent gen kromosom 2, PLEK MERTK EOMES ${ }^{1}$ IL12B' ZNF767, MYC ZFP36L1, BATF, MPV17L2, DKKL1, IL7R1, IL 71, CYP27B11, KIF21B

THEMIS ${ }^{\prime}$, HHEX ${ }^{\prime}$, MAPK1 ${ }^{1}$, SCO2, OLIG3, ZMIZ1, STAT3, TYK2, CD40

Gen uttrykt i immunologiske signalveier screener genomet for flere hunder tusen genpunkter.

Denne første multippel sklerose-GWASstudien ble betraktet som en pilot på grunn av sin moderate størrelse (931 pasienter og foreldre (kontrollpersoner) ble screenet for 334923 enkeltnukleotidpolymorfismer (SNP)), men man lyktes altså å identifisere assosiasjon til to nye gener med små risikobidrag (2). Det var inntil februar 2011 publisert i alt ti GWAS-studier av ulike multippel sklerosepopulasjoner (2, 24, 36-40) som, sammen med replikasjonsstudier (34, 35, 41-52), etablerte en liste på 26 gener assosiert med sykdommen.

De fleste av disse genomvide assosiasjonsstudiene hadde relativt lav statistisk styrke grunnet inklusjon av et moderat antall prøver. Man har derfor antatt at mange multippel sklerose-gener ikke ble identifisert gjennom disse. Ved å slå sammen originaldataene fra flere dem i en felles metaanalyse fikk man økt statistiske styrke og hadde dermed mulighet til å identifisere flere genassosiasjoner (24). Ved hjelp av en slik strategi kunne vår gruppe også med metaanalyse av data fra rundt 10000 multippel sklerose-pasienter og kontrollpersoner vise genomvid signifikant assosiasjon for TYK2-genet, der det beskyttende allelet forekommer med lav frekvens i befolkningen (32).

\section{Nytt multippel sklerose-genkart}

De genomvide assosiasjonsstudiene av multippel sklerose som ble publisert i perioden 2007-10 har alle hatt begrenset styrke og/ eller begrenset dekning av genomet. I 2008 inngikk International MS Genetics Consortium (IMSGC), et verdensomspennende nettverk av grupper som forsket på sykdommen, et samarbeid med Wellcome Trust Case Control Consortium (WTCCC) i Storbritannia for å gjennomføre den best mulige GWASstudien av multippel sklerose. Ca. 20000 multippel sklerose-prøver og 20000 prøver fra kontrollpersoner ble gjort tilgjengelig, og i den første screeningfasen av prosjektet ble totalt 9772 pasienter og 17376 kontrollpersoner genotypet for 441547 enkeltnukleotidpolymorfismer (SNP) (3). Kontrollpersonene er matchet med pasientgruppene i forhold til kjønn og alder samt i henhold til et etnisk genkart som ble etablert ved hjelp av definerte genmarkører. Norge har bidratt med 2072 multippel sklerose-prøver samlet av Oslo MS genetikk gruppe og Norsk MS register og biobank, der 953 pasienter ble inkludert i screeningsfasen av studien.

I studien er det påvist genomvid signifikant assosiasjon $\left(\mathrm{p}<10^{-8}\right)$ og replikert assosiasjon (i 4218 pasienter og 7296 kontrollpersoner) for 52 gener (3). I tillegg er assosiasjon til HLA-DRB1- og -A-alleler bekreftet (tab 1). Av de 52 assosierte ikkeHLA-genene er 23 også identifisert i tidligere studier, mens man i studien påviste 29 nye genområder som sikkert assosiert med multippel sklerose. I tillegg er rundt 50 andre 
genregioner identifisert å være av interesse for videre studier. Et stort flertall på den nye listen over multippel sklerose-assosierte gener er immunrelaterte gener (3). Dette styrker hypotesen om at multippel sklerose primært er en immunmediert sykdom.

Denne nyeste multippel sklerose-GWASstudien inkluderer et tilstrekkelig antall prøver til å kunne identifisere en rekke nye genregioner som er assosiert med sykdommen (3). Studien etablerer dermed et nytt genkart for multippel sklerose, der genregioner man bør vektlegge i oppfølgende studier for å forstå mer av patogenesen ved sykdommen pekes ut. Man kan innvende at genomvide assosiasjonsstudier av multifaktorielle sykdommer kun kan forklare en liten del av sykdomsrisikoen, i og med at bidraget fra hvert enkelt gen er svært moderat. I tillegg må man ved nye strategier prøve å finne også sjeldne genvarianter som ikke kan påvises ved slike studier. Likevel er det et stort fremskritt for multippel sklerose-forskningen at man endelig med sikkerhet har klart å karakterisere flere risikofaktorer. Det må antas at disse genene biologisk sett ikke virker isolert, men at de vil interagere og at den kombinerte effekten er større enn summen av enkelteffektene. Det er derfor god grunn til å anta at genkartet som nå er avdekket, vil være av sentral betydning for forståelsen av sykdomspatogenesen.

\section{Felles autoimmune mekanismer}

Den nylig publiserte multippel skleroseGWAS-studien bekrefter at mange av genregionene som viser assosiasjon til sykdommen, koder for immunologisk relaterte molekyler (3). De genomvide assosiasjonsstudiene har også lært oss at det finnes felles risikogener for ulike immunmedierte sykdommer, blant annet deler multippel sklerose genassosiasjoner med type 1-diabetes, systemisk lupus erythematosus, revmatoid artritt, autoimmun tyreoiditt og inflammatorisk tarmsykdom (53-57).

Antakelig finnes det autoimmune mekanismer som er felles for flere immunmedierte sykdommer. Dette er bakgrunnen for Immunochip-prosjektet, der man har etablert en felles strategi for detaljert kartlegging av genregionene som nå er påvist assosiert med multippel sklerose og andre immunmedierte sykdommer. Oslo MS-genetikkgruppe genotyper nå i underkant av tusen multippel sklerose-pasienter og tilsvarende antall kontrollpersoner i Immunochip-prosjektet og vil samarbeide med nasjonale og internasjonale forskningsgrupper i videre studier.

\section{Veien videre}

Det er beregnet at den nye listen over multippel sklerose-assosierte genregioner kan forklare ca. $20 \%$ av den genetiske assosiasjonen ved sykdommen (3). Dette betyr at man i nye studier må velge andre strategier for å kartlegge den genetiske disposisjonen ved multippel sklerose ytterligere. Helgen- omsekvenseringsstudier, der man avdekker også sjeldne genetiske risikovarianter, antas å være et viktig neste skritt i genkartleggingen av en rekke sykdommer, deriblant multippel sklerose.

I tillegg er det viktig å være klar over at GWAS-resultatene ikke nøyaktig peker ut de involverte genene. Genregionene som nå er påvist, må kartlegges ytterligere for å identifisere nøyaktig hvilke genetiske variasjoner som ligger bak sykdomsassosiasjonene. Dette gjøres i første omgang ved å bekrefte assosiasjonen også i andre populasjoner (replikasjonsstudier), dernest ved å kartlegge i detalj de påviste genområdene ved å studere flest mulig genvariasjoner i det assosierte området (finkartlegging, mapping). I Immunochip-prosjektet kombinerer vi disse to strategiene - vi genotyper de allerede påviste polymorfismene i prøver fra nye multippel sklerose-pasienter og vi analyserer en rekke nye genmarkører i de assosierte genområdene. I andre prosjekter tar man sikte på å kartlegge de assosierte genområdene gjennom storskalert sekvensering.

Omfattende oppfølgingsstudier med vekt på kartlegging av genfunksjon vil også være nødvendig for å avdekke de genetiske mekanismene som er involvert i risikoen for multippel sklerose. Ett eksempel på en oppfølgingsstudie er vår undersøkelse av CLEC16A-genet, som hovedsakelig er uttrykt i immunceller, men der molekylets nøyaktige funksjon ikke er kjent. Vi har gjennom ekspresjonsstudier i blod- og thymusceller funnet at det relative forholdet mellom to alternative CLEC16A-transkripter i celler fra thymus korrelerer med tilstedeværelse av polymorfismer som disponerer for multippel sklerose (33). Videre detaljerte funksjonelle studier av dette og andre molekyler er nødvendig for bedre å forstå mekanismene for utvikling av multippel sklerose så vel som andre autoimmune sykdommer.

Man vil også analysere GWAS-dataene i ulike grupper av multippel sklerose-pasienter, gruppert etter både kliniske variabler, parakliniske variabler (for eksempel MR- og spinalvæskefunn), behandlingsrespons og miljøfaktorer. På denne måten ønsker man å kunne kartlegge ulike geners betydning for det kliniske utrykket av sykdommen, med håp om at dette kan gi opphav til ny kunnskap om patogenesen og lede til mer effektiv terapi.

\section{Fremskritt, men ett skritt om gangen} De siste par årene er det gjort store fremskritt i genetisk multippel sklerose-forskning ved at en rekke nye genregioner som er forbundet med sykdomsrisiko er kartlagt. Det samme gjelder for en rekke andre multifaktorielle sykdommer. Det gjenstår mye forskning for å forklare hvert enkelt gens betydning for utvikling av sykdommen, hvordan de ulike genene virker sammen (gengen-interaksjon) og hvordan miljøfaktorer påvirker genuttrykket (epigenetikk). I translasjonsstudier vil man studere de molekylære mekanismenes betydning for undergrupper av pasienter, sortert etter kliniske og parakliniske variabler, med håp om å kunne skreddersy behandlingen for ulike typer pasienter. Selv om det fortsatt gjenstår mye, representerer de nyeste genetiske studiene av multippel sklerose et viktig skritt i riktig retning.

\section{Hanne F. Harbo (f. 1963)}

er overlege og professor ved Nevrologisk

avdeling, Oslo universitetssykehus, og Institutt for klinisk medisin, Universitetet i Oslo,

og er spesialist i nevrologi.

Ingen oppgitte interessekonflikter.

\section{Åslaug Rudjord Lorentzen (f. 1977)}

er lege med doktorgrad på avhandlingen

Immunogenetic studies in multiple sclerosis.

Ingen oppgitte interessekonflikter.

\section{Benedicte A. Lie (f. 1971)}

er professor og forsker ved Avdeling for medisinsk genetikk og Immunologisk institutt ved Oslo universitetssykehus og Universitetet i Oslo.

Ingen oppgitte interessekonflikter.

\section{Elisabeth Gulowsen Celius (f. 1961)}

er seksjonsoverlege ved Nevrologisk avdeling, Oslo universitetssykehus og spesialist i nevrologi.

Ingen oppgitte interessekonflikter.

\section{Anne Spurkland (f. 1960)}

er professor ved Institutt for medisinske basalfag. Universitetet i Oslo og spesialist i immunologi og transfusjonsmedisin.

Ingen oppgitte interessekonflikter.

Vi takker multippel sklerose-pasienter, kontrollpersoner og forskere som har bidratt til de norske studiene gjennom Oslo MS genetikk gruppe, Norsk MS register og biobank. Norsk beinmargsgiverregister og andre forskningssamarbeid, dessuten International Multiple Sclerosis Genetics Consortium, Wellcome Trust Case Control consortium og Nordic MS Genetics Network for samarbeid i internasjonale prosjekter. Oslo MS-forening, MS-forbundet i Norge, Odd Fellows MS fond, Norges forskningsråd, Helse Sør-Øst, Oslo universitetssykehus, Ullevål, Sanofi-Aventis, Biogen, MerckSerono, Schering, Novartis og Teva Norge har gitt større og mindre bidrag til forskningsprosjekter og reisestøtte. Inger-Lise Mero har gitt nyttige kommentarer til manuskriptet.

\section{Litteratur}

1. Ramagopalan SV, Knight JC, Ebers GC. Multiple sclerosis and the major histocompatibility complex. Curr Opin Neurol 2009; 22: 219-25.

2. Hafler DA, Compston A, Sawcer S et al. Risk alleles for multiple sclerosis identified by a genomewide study. N Engl J Med 2007; 357: 851-62. 
3. Sawcer S, Hellenthal G. Pirinen M et al Genetic risk and a primary role for cell-mediated immune mechanisms in multiple sclerosis. Nature 2011; 476: $214-9$

4. Río J, Comabella M, Montalban X. Multiple sclerosis: current treatment algorithms. Curr Opin Neurol 2011; 24: $230-7$

5. Smestad C, Sandvik L, Holmoy T et al. Marked differences in prevalence of multiple sclerosis between ethnic groups in Oslo, Norway. J Neurol 2008; 255: 49-55.

6. Harbo HF, Utsi E, Lorentzen AR et al. Low frequency of the disease-associated DRB1*15DQB $1 * 06$ haplotype may contribute to the low prevalence of multiple sclerosis in Sami. Tissue Antigens 2007; 69: 299-304

7. Celius EG, Smestad C. Change in sex ratio, disease course and age at diagnosis in Oslo MS patients through seven decades. Acta Neurol Scand Suppl 2009; 120: 27-9.

8. Ebers GC. A twin consensus in MS. Mult Scler 2005: 11: 497-9

9. Hammond SR, English DR, McLeod JG. The agerange of risk of developing multiple sclerosis: evidence from a migrant population in Australia. Brain 2000; 123: 968-74.

10. Hayes CE, Cantorna MT, DeLuca HF. Vitamin D and multiple sclerosis. Proc Soc Exp Biol Med 1997; 216: $21-7$

11. Munger KL, Levin LI, Hollis BW et al. Serum 25hydroxyvitamin $D$ levels and risk of multiple scler osis. JAMA 2006; 296: 2832-8.

12. Ahlgren $C$, Torén $K$, Odén A et al. A populationbased case-control study on viral infections and vaccinations and subsequent multiple sclerosis risk. Eur J Epidemiol 2009; 24: 541-52.

13. Ascherio A, Munger KL. Environmental risk factor for multiple sclerosis. Part II: Noninfectious factors. Ann Neurol 2007; 61: 504-13.

14. Jersild C, Svejgaard A, Fog T. HL-A antigens and multiple sclerosis. Lancet 1972; 1: 1240-1.

15. Naito S, Namerow N, Mickey MR et al. Multiple sclerosis: association with HL-A3. Tissue Antigens 1972; 2: 1-4.

16. McFarland HF, Martin R. Multiple sclerosis: a complicated picture of autoimmunity. Nat Immunol 2007; 8: 913-9.

17. Jersild C, Fog T, Hansen GS et al. Histocompatibility determinants in multiple sclerosis, with special reference to clinical course. Lancet 1973; 2: $1221-5$

18. Olerup 0, Hillert J. HLA class II-associated genetic susceptibility in multiple sclerosis: a critical evalu ation. Tissue Antigens 1991; 38: 1-15.

19. Dyment DA, Herrera BM, Cader MZ et al. Complex interactions among $\mathrm{MHC}$ haplotypes in multiple sclerosis: susceptibility and resistance. Hum Mol Genet 2005; 14: 2019-26.

20. Lincoln MR, Ramagopalan SV, Chao MJ et al. Epistasis among HLA-DRB1, HLA-DQA1, and HLADQB1 loci determines multiple sclerosis susceptibility. Proc Natl Acad Sci U S A 2009; 106: 7542-7.

21. Brynedal B, Duvefelt K, Jonasdottir G et al. HLA-A confers an HLA-DRB1 independent influence on the risk of multiple sclerosis. PLoS ONE 2007; 2 e664.

22. Harbo HF, Lie BA, Sawcer S et al. Genes in the HLA class I region may contribute to the HLA class II-associated genetic susceptibility to multiple sclerosis. Tissue Antigens 2004; 63 : 237-47.

23. Yeo TW, De Jager PL, Gregory SG et al. A second major histocompatibility complex susceptibility locus for multiple sclerosis. Ann Neurol 2007; 61: 228-36.

24. De Jager PL, Jia X, Wang J et al. Meta-analysis of genome scans and replication identify CD6, IRF8 and TNFRSF1A as new multiple sclerosis susceptibility loci. Nat Genet 2009; 41: 776-82.

25. Lorentzen AR, Karlsen TH, Olsson M et al. Killer immunoglobulin-like receptor ligand HLA-Bw4 protects against multiple sclerosis. Ann Neurol 2009; 65: 658-66.

26. Rolstad B, Vaage JT, Naper $C$ et al. Positive and negative MHC class I recognition by rat NK cells. Immunol Rev 1997; 155: 91-104.

27. Naper C, Ryan JC, Nakamura MC et al. Identification of an inhibitory $\mathrm{MHC}$ receptor on alloreactive rat natural killer cells. J Immunol 1998; 160: 219-24.

28. Dupont WD, Plummer WD Jr. Power and sample size calculations. A review and computer program Control Clin Trials 1990; 11: 116-28.

29. Sawcer S. A new era in the genetic analysis of multiple sclerosis. Curr Opin Neurol 2006: 19: 237-41.

30. Gasser T. Autosomal-dominantly inherited forms of Parkinson's disease. J Neural Transm Suppl 2000; nr. 58: 31-40.

31. Harbo HF Mørk S, Vedeler C et al. Biobank for multippel sklerose etablert. Tidsskr Nor Lægeforen 2007; 127: 2276.

32. Mero IL, Lorentzen AR, Ban M et al. A rare varian of the TYK2 gene is confirmed to be associated with multiple sclerosis. Eur J Hum Genet 2010; 18 : $502-4$

33. Mero IL, Ban M, Lorentzen AR et al. Exploring the CLEC16A gene reveals a MS-associated variant with correlation to the relative expression of CLEC16A isoforms in thymus. Genes Immun 2011 12: 191-8.

34. Gregory SG, Schmidt S, Seth $P$ et al. Interleukin 7 receptor alpha chain (IL7R) shows allelic and functional association with multiple sclerosis. Nat Genet 2007: 39: 1083-91.

35. Lundmark F, Duvefelt K, lacobaeus E et al. Variation in interleukin 7 receptor alpha chain (IL7R) influences risk of multiple sclerosis. Nat Genet 2007: 39: 1108-13.

36. Comabella M, Craig DW, Camiña-Tato M et al. Identification of a novel risk locus for multiple sclerosis at $13 q 31.3$ by a pooled genome-wide scan of 500,000 single nucleotide polymorphisms. PLOS ONE 2008: 3: e3490.

37. Aulchenko YS, Hoppenbrouwers IA, Ramagopalan SV et al. Genetic variation in the KIF1B locus influ ences susceptibility to multiple sclerosis. Nat Genet 2008; 40: 1402-3.

38. Baranzini SE, Wang J, Gibson RA et al. Genomewide association analysis of susceptibility and clinical phenotype in multiple sclerosis. Hum Mol Genet 2009; 18: 767-78.

39. Bahlo M, Booth DR, Broadley SA et al. Genomewide association study identifies new multiple sclerosis susceptibility loci on chromosomes 12 and 20. Nat Genet 2009; 41: 824-8

40. Jakkula E, Leppä V Sulonen AM et al. Genomewide association study in a high-risk isolate for multiple sclerosis reveals associated variants in STAT3 gene. Am J Hum Genet 2010; 86: 285-91.

41. Sanna S, Pitzalis M, Zoledziewska M et al. Variants within the immunoregulatory CBLB gene are associated with multiple sclerosis. Nat Genet 2010; 42: 495-7.

42. Weber F, Fontaine B, Cournu-Rebeix I et al. IL2RA and IL7RA genes confer susceptibility for multiple sclerosis in two independent European populations. Genes Immun 2008; 9: 259-63.

43. Booth D, Heard R, Stewart $G$ et al. Refining genetic associations in multiple sclerosis. Lancet Neurol 2008: 7: 567-9

44. Rubio JP, Stankovich J, Field J et al. Replication of KIAA0350, IL2RA, RPL5 and CD58 as multiple sclerosis susceptibility genes in Australians. Genes Immun 2008; 9: 624-30.

45. Alcina A, Fedetz M, Ndagire D et al. IL2RA/CD25 gene polymorphisms: uneven association with multiple sclerosis (MS) and type 1 diabetes (T1D). PLoS ONE 2009; 4: e4137.

46. Akkad DA, Hoffjan S, Petrasch-Parwez E et al. Variation in the IL7RA and IL2RA genes in German multiple sclerosis patients. J Autoimmun 2009; 32 110-5.

47. Alcina A, Fedetz M, Ndagire D et al. The T244I variant of the interleukin-7 receptor-alpha gene and multiple sclerosis. Tissue Antigens 2008; 72 : 158-61.

48. Hoppenbrouwers IA, Aulchenko YS, Ebers GC et al. EVI5 is a risk gene for multiple sclerosis. Genes Immun 2008; 9: 334-7.

49. Hafler JP, Maier LM, Cooper JD et al. CD226 Gly307Ser association with multiple autoimmune diseases. Genes Immun 2009; 10: 5-10.

50. Ban M, Goris A, Lorentzen AR et al. Replication analysis identifies TYK2 as a multiple sclerosis susceptibility factor. Eur J Hum Genet 2009; 17: 1309-13.

51. Ban M, McCauley JL, Zuvich R et al. A non-synonymous SNP within membrane metalloendopeptidase-like 1 (MMEL1) is associated with multiple sclerosis. Genes Immun 2010; 11: 660-4.

52. McCauley JL, Zuvich R, Beecham AL et al. Com prehensive follow-up of the first genome-wide association study of multiple sclerosis identifies KIF21B and TMEM39A as susceptibility loci. Hum Mol Genet 2010; 19: 953-62

53. Booth DR, Heard RN, Stewart GJ. The expanding genetic overlap between multiple sclerosis and type I diabetes. Genes Immun 2009; 10: 11-4.

54. Martínez A, Perdigones N, Cénit MC et al. Chromosomal region 16p13: further evidence of increased predisposition to immune diseases. Ann Rheum Dis 2010; 69: 309-11.

55. Zoledziewska M, Costa G, Pitzalis M et al. Variation within the CLEC16A gene shows consistent disease association with both multiple sclerosis and type 1 diabetes in Sardinia. Genes Immun 2009; $10: 15-7$

56. Burton PR, Clayton DG, Cardon LR et al. Association scan of 14,500 nonsynonymous SNPs in four diseases identifies autoimmunity variants. Nat Genet 2007; 39: 1329-37.

57. Zhernakova A, van Diemen CC, Wijmenga C Detecting shared pathogenesis from the shared genetics of immune-related diseases. Nat Rev Genet 2009: 10: 43-55.

Mottatt 22.8. 2010, første revisjon innsendt 7.3. 2011, godkjent 11.8. 2011. Medisinsk redaktør Jon Amund Kyte. 